\title{
A comparative study of Butacote and Naprosyn in ankylosing spondylitis
}

BARBARA M. ANSELL*, G. MAJOR*,S. P. LIYANAGE $\dagger$, J.M. GUMPEL + , क M. H. SEIFERT**, J.A. MATHEWS $\dagger \dagger$, AND C. ENGLER $\ddagger \ddagger$

From the Canadian Red Cross Hospital, Taplow*, Heatherwood Hospital, Ascot $\dagger$, Northwick Park Hospital,,$\vec{\omega}$ Harrow + , St. Mary's Hospital, London**, St. Thomas's Hospital, London $\dagger$, and Syntex Pharmaceuticals Ltd., Maidenhead $\ddagger$

SUMMARY A double-blind, cross-over comparison of Naprosyn* (naproxen) $750 \mathrm{mg}$ daily andi Butacote* (enteric-coated phenylbutazone) $300 \mathrm{mg}$ daily was carried out in a multi-centre trial. Twenty-five patients, mostly male and under 40 years of age, were entered. After a 2-week period ino which any existing anti-inflammatory drugs were tailed off, patients were entered into the trial and ${ }_{-}$ treated for 1 month with each drug. Patients were assessed at 4-weekly intervals. Both drugs signifi-O cantly reduced morning stiffness. Morning pain and discomfort and wall-tragus distance were alsoô significantly reduced by both drugs during the trial. Results of the Schober test showed improvement电 during both treatment periods. There were no overall statistically significant differences between the $\frac{\vec{\theta}}{\bullet}$ effects of the 2 drugs on objective parameters. However, overall subjective assessment of symptoms $\infty$ showed a greater improvement on Butacote. Treatment preferences by physician and subjective assessment by the patient both favoured Butacote but the difference between the 2 drugs was not? statistically significant. Side effects were mostly of a minor nature. One patient had to discontinue $\frac{\partial}{\bar{O}}$ the trial, due to indigestion while taking Butacote.

Since the original reports of Hart (1953), phenylbutazone has been accepted as an effective medication for ankylosing spondylitis and its prolonged use in this condition, as reported by Mason and Howes (1963), showed it to be a most satisfactory treatment, although there has always been some anxiety as to the possibility of blood dyscrasias developing. In 1973, Hill and Hill, in an open trial with a placebo pulse, reported on the successful use of naproxen in managing ankylosing spondylitis. They updated this report (Hill and Hill, 1976) after gathering up to 30 months' experience in some patients. Subsequently a pilot study was set up to compare Naprosyn $500 \mathrm{mg}$ daily with $300 \mathrm{mg}$ of Butacote daily when it was noted that Naprosyn was slightly less effective than Butacote (Mathews et al., 1975). The present study was undertaken to compare a daily dose of $750 \mathrm{mg}$ naproxen (one $250 \mathrm{mg}$ tablet in the morning and 2 tablets at night) with phenylbutazone enteric-coated tablets (Butacote) 100 $\mathrm{mg} 3$ times a day. Butacote was given as it had been shown to have better gastrointestinal tolerance than phenylbutazone (Rushford and Fowler, 1970).

Accepted for publication December 12, 1977

*Naprosyn-Syntex Pharmaceuticals Ltd. Butacote-Geigy Pharmaceuticals Ltd.

\section{Material and methods}

The trial was a double-blind, cross-over study with double dummy technique so that the active drugs: could be presented as the standard commercial $\frac{0}{2}$ preparations. It was carried out in 5 centres, allo using the same protocol. Patients were admitted 3 . only if they had radiographic evidence of sacroiliitis of at least grade 2 (Atlas of Standard Radiographs of Arthritis, 1963) and if they had clinicallyo active symptoms. The latter was determined during the run-in period when current therapy was graduallyo reduced so that paracetamol only was taken during the last 5 days. Following this 2 week run-in period, 0 provided there had been a deterioration in at least $N$ 2 of the parameters measured, the patients were N admitted into the trial. They were then given each preparation for 4 weeks, the order of treatment being randomised.

Patients were excluded if they were suffering from significant renal, hepatic or cardiac disease, diseases likely to be associated with sacroiliitis (eg, psoriasis), a history of untoward reaction to either drug, peptic ulcer, or if they were likely to become pregnant.

At all visits the following parameters (Table 1) were assessed: morning stiffness, immobility stiffness, 


\section{Table 1 Assessment parameters}

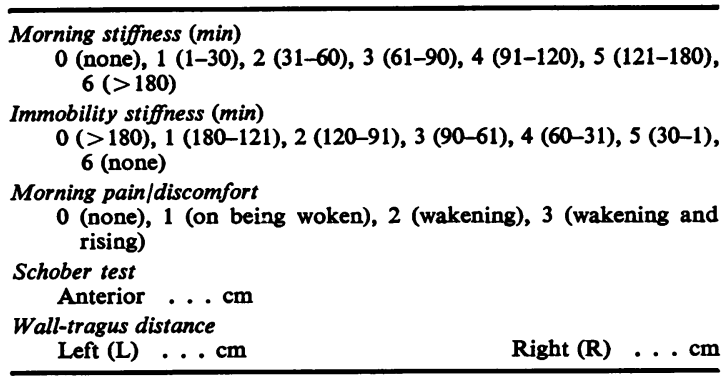

morning pain, Schober test (Moll and Wright 1971), and wall-tragus distance.

In addition, global assessment of severity of symptoms $(0=$ no symptoms, $1=$ mild, $2=$ moderate, $3=$ severe) was made as well as a subjective comparison of the patient's overall state with that at the previous visit $(-2=$ much worse, $-1=$ worse, $0=$ about the same, $+1=$ better, $+2=$ much better). At the end of the trial patients and doctors reported their opinion as to which period of treatment they preferred.

Side effects were elicited by indirect questioning. Routine blood tests and urine analysis were done at each visit. Statistical significance of any changes or differences between the effects of the 2 drugs was determined using Wilcoxon's signed rank test.

For analysis patients were split into two groups: group I, Naprosyn given during the first period of treatment, and group II, Butacote given during the first period of treatment. Changes from baseline and differences between groups were calculated. A test on the pooled data was also done.

\section{Results}

Twenty-five patients were entered into the trial, of whom 23 were males. Over two-thirds were under 40 years of age and except for a few cases the duration of the disease was below 15 years (Table 2). The initial findings at day 0 are given in Table 3. For morning stiffness the 2 groups were significantly different at day 0 . This was due to a significant deterioration during the run-in period in group I but not in group II. The changes from baseline during therapy are given in Table 4.

Table 2 Patients (23 males, 2 females)

\begin{tabular}{|c|c|c|c|c|c|c|}
\hline $\begin{array}{l}\text { Age (years) } \\
\text { No. of patients }\end{array}$ & $\begin{array}{l}20-29 \\
6\end{array}$ & 9 & $\begin{array}{rr}-39 & 4 \\
2 \\
\text { ange } 25\end{array}$ & & $\begin{array}{l}50-59 \\
3\end{array}$ & $\begin{array}{l}60-69 \\
2\end{array}$ \\
\hline $\begin{array}{l}\text { Disease duration } \\
\text { (years) } \\
\text { No. of patients }\end{array}$ & $\begin{array}{l}0-5 \\
6\end{array}$ & $\begin{array}{l}6-10 \\
6\end{array}$ & $8^{11-15}$ & $l^{16-20}$ & $\begin{array}{l}21-25 \\
1\end{array}$ & $3^{>25}$ \\
\hline
\end{tabular}

Table 3 Initial findings at day 0

\begin{tabular}{|c|c|c|c|}
\hline \multirow[t]{2}{*}{ Parameter } & \multicolumn{2}{|l|}{ Mean value $\pm S D$} & \multirow[t]{2}{*}{$\boldsymbol{P}$} \\
\hline & Group I & Group II & \\
\hline $\begin{array}{l}\text { Morning stiffness (0-6) } \\
\text { Immobility stiffness (6-0) } \\
\text { Morning pain (0-3) } \\
\text { Schober test (cm) } \\
\text { Wall-tragus L (cm) } \\
\text { R (cm) }\end{array}$ & $\begin{array}{r}3 \cdot 71 \pm 2.09 \\
2.57 \pm 1.78 \\
1.50 \pm 0.94 \\
3.25 \pm 2.07 \\
15.07 \pm 5.23 \\
15.57 \pm 5.69\end{array}$ & $\begin{array}{r}2.00 \pm 1.48 \\
2.54 \pm 1.51 \\
1.45 \pm 1.04 \\
3.34 \pm 1 \cdot 84 \\
15.23 \pm 4 \cdot 11 \\
15.36 \pm 4 \cdot 18\end{array}$ & $\begin{array}{l}0.05 \\
\text { NS } \\
\text { NS } \\
\text { NS } \\
\text { NS } \\
\text { NS }\end{array}$ \\
\hline $\begin{array}{l}\text { Haemoglobin } \\
(\mathrm{mg} / 100 \mathrm{ml}) \\
\text { ESR }(\mathrm{mm} / \mathrm{h})\end{array}$ & $\begin{array}{l}14.02 \pm 1.13 \\
26.31 \pm 13.97\end{array}$ & $\begin{array}{l}13.42 \pm 1.17 \\
28.82 \pm 19.31\end{array}$ & $\begin{array}{l}\text { NS } \\
\text { NS }\end{array}$ \\
\hline
\end{tabular}

\section{MORNING STIFFNESS}

Both drugs produced significant improvements compared to baseline. No significant differences between the effects of the 2 drugs were demonstrated.

\section{IMMOBILITY STIFFNESS}

Neither drug produced any significant change in this parameter and there was no difference between the effects of the drugs.

\section{MORNING PAIN AND DISCOMFORT}

Morning pain and discomfort decreased significantly in both groups during the first 4-week period but after the cross-over, a deterioration occurred and the change from baseline was no longer statistically significant. There was no difference between the effects of the 2 drugs.

\section{SCHOBER TEST}

Both drugs produced mean positive changes in the Schober test but only the change in group II during the second phase (Naprosyn) was statistically significant. Evidence of a carry-over effect from the previous therapy exists and there is no difference between the effects of the 2 drugs.

WALL-TRAGUS DISTANCE

This parameter for both left and right measurements decreased on both drugs. However, the changes were only significant in group II.

\section{HAEMOGLOBIN}

A non-significant fall occurred in group I on Naprosyn; a significant rise occurred in patients in group II during both treatment periods. The changes were small and no patient developed a haemoglobin level outside the normal range.

ESR

A statistically significant fall in the erythrocyte sedimentation rate (ESR) occurred in the second phase of group I (Butacote). The overall difference between the effects of the 2 drugs shows a statistical difference $(P=0.05)$ but there is also evidence of a carry-over effect. 
Table 4 Mean changes from week 0

\begin{tabular}{|c|c|c|c|c|}
\hline \multirow[t]{3}{*}{ Parameter } & \multicolumn{4}{|c|}{ Mean change $\pm S D$} \\
\hline & \multicolumn{2}{|l|}{ Group I } & \multicolumn{2}{|l|}{ Group II } \\
\hline & Naprosyn & Butacote & Butacote & Naprosyn \\
\hline $\begin{array}{l}\text { Morning stiffness } \\
\text { Immobility stiffness } \\
\text { Morning pain } \\
\text { Schober test } \\
\text { Wall-tragus L } \\
\quad \mathbf{R} \\
\text { Haemoglobin } \\
\text { ESR }\end{array}$ & $\begin{array}{l}-1 \cdot 71 \pm 2.49 * \\
-0.14 \pm 1.92 \\
-0.85 \pm 0.99^{*} \\
+0.42 \pm 0.89 \\
-0.16 \pm 1.40 \\
-0.51 \pm 1.10 \\
-0.15 \pm 0.53 \\
+2.17 \pm 11.97\end{array}$ & $\begin{array}{l}-1.71 \pm 2.46^{*} \\
+0.14 \pm 2.25 \\
-0.57 \pm 1.22 \\
+0.68 \pm 1.19 \\
-0.09 \pm 1.36 \\
-0.14 \pm 1.38 \\
+0.06 \pm 0.90 \\
-9.15 \pm 8.59 \dagger\end{array}$ & $\begin{array}{l}-1 \cdot 36 \pm 1.63^{*} \\
-0.09 \pm 2.26 \\
-1 \cdot 18 \pm 1.08 \dagger \\
+0.90 \pm 2.42 \\
-1.14 \pm 1.61^{*} \\
-1 \cdot 14 \pm 1.52^{*} \\
+0.35 \pm 0.36^{*} \\
-3.54 \pm 10.48\end{array}$ & $\begin{array}{l}-0.82 \pm 0.98^{*} \\
-0.82 \pm 1.94 \\
-0.64 \pm 1.90 \\
+1.32 \pm 0.83 \dagger \\
-1.91 \pm 1.51^{*} \\
-1.21 \pm 1.80^{*} \\
+0.41 \pm 0.59^{*} \\
-6.20 \pm 9.95\end{array}$ \\
\hline
\end{tabular}

${ }^{*} \mathrm{P}<0.05 \quad \dagger \mathrm{P}<0.01$

Table 5 Subjective assessments

\begin{tabular}{|c|c|c|c|c|}
\hline \multirow[t]{3}{*}{ Parameter } & \multicolumn{4}{|c|}{ Mean value $\pm S D$} \\
\hline & \multicolumn{2}{|l|}{ Group I } & \multicolumn{2}{|l|}{ Group II } \\
\hline & Naprosyn & Butacote & Butacote & Naprosyn \\
\hline $\begin{array}{l}\text { Comparison } \\
(-2 \text { to }+2 \\
\text { Physician } \\
\text { Patients }\end{array}$ & $\begin{array}{l}+0.61 \pm 1.04 \\
+0.64 \pm 1.08^{*}\end{array}$ & $\begin{array}{l}+0.31 \pm 1.03 \\
+0.34 \pm 1.15\end{array}$ & $\begin{array}{l}+1 \cdot 10 \pm 0.74 \dagger \\
+1 \cdot 27 \pm 1 \cdot 10 \dagger\end{array}$ & $\begin{array}{l}-0.50 \pm 0.53 \\
-0.36 \pm 0.67\end{array}$ \\
\hline $\begin{array}{c}\text { Overall symp } \\
\text { Physician } \\
\text { Pattents }\end{array}$ & $\begin{array}{l}1.61 \pm 0.65 \\
1.71 \pm 0.73\end{array}$ & $\begin{array}{l}1 \cdot 50 \pm 0 \cdot 80 \\
1 \cdot 29 \pm 1 \cdot 14\end{array}$ & $\begin{array}{l}1.00 \pm 0.47 \\
1.27 \pm 0.33\end{array}$ & $\begin{array}{l}1.22 \pm 0.44 \\
1.55 \pm 0.52\end{array}$ \\
\hline
\end{tabular}

The overall views of symptoms and comparison with previous visit are given in Table 5. In group I, all mean changes were positive compared with the previous visit and the patient's assessment on Naprosyn was statistically significant. In group II both patients' and physicians' subjective assessment showed a significant improvement during the first phase (Butacote) but a deterioration during the second phase (Naprosyn). Subjective assessment of severity of symptoms was graded lower on Butacote than on Naprosyn and the patients' subjective assessments of the differences between the effects of the 2 drugs was statistically significant $(P=0 \cdot 03)$.

The preference at the end of treatment is shown in Table 6. Butacote was preferred more times than Naprosyn but the difference is not statistically significant.

-Side effects elicited by indirect questioning were slightly more in number on Butacote (16) than on Naprosyn (13). The number of patients reporting side effects was 8 on each drug. These side effects were

Table 6 Treatment preference

\begin{tabular}{llllll}
\hline & $\begin{array}{l}\text { Naproxen } \\
\text { much } \\
\text { better }\end{array}$ & $\begin{array}{l}\text { Naproxen } \\
\text { better }\end{array}$ & $\begin{array}{l}\text { Both } \\
\text { periods } \\
\text { equal }\end{array}$ & $\begin{array}{l}\text { Butacote } \\
\text { better }\end{array}$ & $\begin{array}{l}\text { Butacote } \\
\text { much } \\
\text { better }\end{array}$ \\
\hline Patient & 4 & 2 & 4 & 11 & 4 \\
Physician & 2 & 4 & 7 & 8 & 4 \\
\hline
\end{tabular}

generally non-specific but several patients complained of indigestion and sore mouth. One patient dis- $\overrightarrow{\vec{P}}$ continued medication while on Butacote.

\section{Discussion}

Naprosyn and Butacote have both been shown too improve morning stiffness, morning pain, and wall-o tragus distance in patients suffering from ankylosing spondylitis. Although specific measurements showedô no real differences between the drugs, Butacote was favoured according to the global assessments by physicians and significantly so by patients.

As far as the 2 treatment groups are concerned, group II showed a higher number of statisticallyn significant differences from baseline than did group I. The only difference between the groups at baselineo was in the duration of morning stiffness. However, thew duration of morning stiffness decreased significantlye during treatment in both groups of patients. It maxo be that the order of medication in group II, Butacoted followed by Naprosyn, produced the difference.

Phenylbutazone preparations have been used for 0 more than 25 years in the treatment of ankylosing spondylitis. It is an effective drug with a well-definedo position amongst the available treatments. However $\mathbb{\Omega}$ side effects, including the occasional severe bloodo dyscrasia, are well documented. Naprosyn is $a_{0}$ 
relatively new drug which is being used extensively in the treatment of various rheumatic disorders. Serious side effects while occasionally recorded, are comparatively rare (Cuthbert, 1974).

It is suggested from this study that Naprosyn will have a useful place in the management of ankylosing spondylitis.

We thank Dr. P Fowler of Geigy Pharmaceuticals for providing the Butacote and placebo used in this study, and Dr. P Freeman of University College London, London for carrying out the statistical analysis.

\section{References}

Atlas of Standard Radiographs of Arthritis, Vol. 2. (1963) Blackwell: London/Oxford.

Cuthbert, M. (1974). Adverse reactions to non-steroidal antirheumatic drugs. Current Medical Research and Opinion, 2, 600-610.
Hart, F. D. (1953). Phenylbutazone (Butazolidin). Practitioner, 171, 84-94.

Hill, H. F. H., and Hill, A. G. S. (1973). Naproxen in ankylosing spondylitis. Scandinavian Journal of Rheumatology, Suppl. 2, 121-126.

Hill, H. F. H., and Hill, A. G. S. (1976). Naproxen in treatment of ankylosing spondylitis. Annals of the Rheumatic Diseases, 35, 287-288.

Mason, R. M., and Howes, R. G. (1963). The treatment of ankylosing spondylitis. In Proceedings of the Australian Rheumatism Congress, p. 51-57, Sydney, September 1963.

Mathews, J. A., Ansell, B. M., Gumpel, J. M., and Lloyd, K. N. (1975). Naproxen in ankylosing spondylitis. A pilot double-blind comparative trial with phenylbutazone. Proceedings of the Naproxen Round Table Meeting, VIII European Rheumatology Congress, Helsinki: 14, edited by M. Stoppard. Syntex: Maidenhead.

Moll, J. M. H., and Wright, V. (1971). Normal range of spinal mobility. Annals of the Rheumatic Diseases, 30, 381-386.

Rushford, W. A. I., and Fowler, P. D. (1970). Assessment of enteric-coated phenylbutazone in general practice. Practitioner, 205, 671-676. 